\title{
Resepsi Terhadap Alquran Dalam Riwayat Hadis
}

\author{
Oleh: Nilna Fadlillah
}

Email: nilna.fa@gmail.com

\section{Pon Pes Aji Mahasiswa Al Muhsin, Yogyakarta}

\begin{abstract}
Abstrak
Pembacaan Alquran yang dilakukan oleh umat Islam tidak hanya bertujuan untuk beribadah atau kepentingan akhirat semata, akan tetapi juga memiliki kepentingan lain. Di satu sisi terdapat pembacaan yang bersifat formal-subtantif yaitu pembacaan yang dilakukan dalam konteks ibadah yang lebih berorientasi pada keuntungan atau pahala akhirat. Di sisi lain, pembacaan Alquran juga dilakukan secara fungsional yang orientasi keuntungannya lebih bersifat duniawi. Fenomena pembacaan Alquran dalam berbagai bentuknya ini masuk dalam salah satu bidang kajian living Quran atau resepsi Alquran. Dalam tulisan ini, peneliti akan berusaha melihat beragam resepsi dalam Alquran dengan menjadikan hadis sebagai objek formal penelitian. Dengan memetakan riwayatriwayat tentang resepsi Alquran yang dilakukan oleh generasi awal Islam yang terekam dalam riwayat hadis, selanjutnya tulisan ini juga akan melihat proses transmisi dan tranformasi riwayat hadis sehingga sampai saat ini resepsi Alqurantetap eksis dan variatif.
\end{abstract}

Kata Kunci: Living Quran, Hadis, Transmisi, Transformasi 


\section{Pendahuluan}

Dengan berbagai aspek yang dimiliki, Alquran senantiasa meliputi kehidupan manusia. Selain mengandung berbagai hal yang menjadi way of life umat Islam, - mulai dari aspek akidah, akhlak, ibadah, hukum-hukum, hingga persoalan sosial - Alquranjuga senantiasa dibaca oleh umat Islam karena memiliki nilai ibadah. ${ }^{1}$ Akan tetapi, pada praktiknya, pembacaan Alquran yang dilakukan oleh umat Islam tidak hanya bertujuan untuk beribadah atau kepentingan akhirat semata, akan tetapi juga memiliki kepentingan lain.

Secara teoretis, Ahmad Rafiq menjelaskan bahwa model-model pembacaan Alquran tersebut ada yang dilakukan secara formalsubtantif yaitu pembacaan yang dilakukan dalam konteks ibadah yang lebih berorientasi pada keuntungan atau pahala akhirat. Di sisi lain, pembacaan Alquran juga dilakukan secara fungsional yang orientasi keuntungannya lebih bersifat duniawi. ${ }^{2} \mathrm{Di}$ antara model pembacaan Alquran yang dilakukan di luar konteks ibadah ditemukan oleh Irmeli Perho. Di dalam artikelnya, dia menjelaskan bahwa pembacaan ayatayat tertentu di dalam Alquran dengan berbagai cara juga seringkali dilakukan untuk pengobatan. ${ }^{3}$ Selain itu, praktik pembacaan Alquran juga terdapat pada praktik yang dilakukan pada waktu, tempat dan tujuan tertentu, misalnya praktik pembacaan yang dilakukan pada malam Jum'at tengah malam di makam para wali atau ulama sebagai sarana untuk memohon sesuatu. ${ }^{4}$ Di dalam kajian akademik, fenomena

1 Argumen ini dikemukakan oleh para ulama dalam mendefinisikan Alquran sebagai kalam Allah yang berupa mukjizat yang diturunkan kepada Nabi Muhammad SAW, tertulis di dalam mushaf-mushaf, diriwayatkan secara mutawattir, dan mempunyai nilai ibadah dengan membacanya. Lihat misalnya dalam al-Zarqani, Manāhil al-'Urfän, Juz I (Beirut: Dār al-Kutub al-'Ilmiyyah, 1996), hlm. 20.

2 Ahmad Rafiq, "Faḍāil al-Qur’ān" dalam Abdul Mustaqim, dkk, Melihat Kembali Studi Alquran: Gagasan, Isu, dan Tren Terkini (Yogyakarta: Idea Press, 2015), hlm. 42-43.

3 Irmeli Perho, "Pengobatan dan Alquran" dalam Syahiron Syamsuddin (ed.), AlquranSains dan Ilmu Sosial, terj. Lien Iffah Naf'atu Fina dan Ari Hendri (Yogyakarta:eLSAQ Press, 2010), hlm. 84.

4 Muhammad, "Mengungkap Pengalaman Muslim Berinteraksi dengan Alquran" dalam Sahiron Syamsudin (ed.), Metodologi Penelitian Living Qur'an dan Hadis (Yogyakarta: TH Press, 2007), hlm. 15. 
pembacaan Alquran dalam berbagai bentuknya ini masuk dalam salah satu bidang kajian living Qur'an atau resepsi Alquran yang merupakan suatu kajian atau uraian tentang cara seseorang menerima, merespon, memanfaatkan atau menggunakannya baik sebagai teks yang memuat susunan sintaksis atau sebagai mushaf yang memiliki maknanya sendiri. $^{5}$

Adapun model pembacaan Alquran secara fungsional - yang seringkali dibaca dengan berbagai latar belakang, motivasi, atau harapan tertentu di luar makna teks ayat, ternyata juga sudah dilakukan sejak masa awal Islam dan direspon secara kreatif dari generasi ke generasi hingga saat ini. Untuk melihat ragam fenomena tersebut di masa awal Islam, tulisan ini mencoba untuk memetakan riwayat-riwayat tentang resepsi Alquran yang dilakukan oleh generasi awal Islam yang terekam dalam riwayat hadis. Berangkat dari informasi yang terdapat di dalam riwayat tersebut, tulisan ini juga akan melihat proses transmisi dan tranformasi riwayat hadis sehingga sampai saat ini, resepsi Alquran tetap eksis dan variatif.

\section{PEMBAHASAN}

\section{A. Resepsi Formal-Substansial terhadap Alquran}

Menurut Ingrid Mattson, membaca Alquran adalah pusat aktivitas ibadah, karena setiap hari, umat Islam minimal wajib membaca Alquran dalam ibadah salat lima waktu. ${ }^{6}$ Terkait dengan hal ini, terdapat salah satu riwayat bahwa Nabi pernah menjawab pertanyaan sahabat tentang amal yang paling utama. Beliau menjawab membaca Alquran di dalam salat merupakan amal yang paling utama di sisi Allah. $^{7}$

5 Ahmad Rafiq, "Sejarah Alquran: Dari Pewahyuan ke Resepsi (Sebuah Pencarian Awal Metodologis)" dalam Sahiron Syamsudin (ed.), Islam, Tradisi dan Peradaban (Yogyakarta: Suka Press, 2012), hlm. 73.

6 Ingrid Mattson, Ulumul Quran Zaman Kita (Jakarta: Zaman, 2013), hlm. 163

7 Al-Qurthubi, The Secret of Qur'an, terj. Muhammad Syafi'i Masykur (Yogyakarta: Mitra Pustaka, 2013), hlm. 139 
Abdullah bin Mas'ud pernah meriwayatkan suatu hadis dari Nabi Muhammad bahwa orang yang membaca satu huruf dari Alquran akan memperoleh pahala sepuluh kebaikan. ${ }^{8}$ Baik dibaca dengan lancar atau pun tidak, Allah tetap menjanjikan pahala bagi pembacanya. Salah satu riwayat hadis menceritakan bahwa orang yang mahir membaca Alquran akan bersama-sama dengan para malaikat, sedangkan orang yang tersendat-sendat ketika membaca Alquran karena merasa kesulitan akan mendapatkan dua pahala. ${ }^{9}$ Riwayat-riwayat di atas merupakan sebagian dari keutamaan yang dimiliki oleh Alquran. Di samping keutamaan berupa pahala, Alquran juga memberikan keuntungan bagi pembacanya ketika telah di akhirat nanti. Dalam riwayat hadis lain, Nabi pernah memerintahkan para sahabat untuk membaca Alquran karena di hari kiamat nanti ia akan menjadi syafaat bagi pembacanya. ${ }^{10}$

Selain itu, orang yang belajar dan mengajarkan Alquran juga disebut oleh Nabi sebagai orang yang paling utama. ${ }^{11}$ Dalam hal ini umat Islam pun berlomba-lomba agar dapat menjadi golongan tersebut. Sejak masa Nabi, Alquran diajarkan ke berbagai daerah oleh para sahabat. Ketika Islam mulai disebarkan ke berbagai wilayah di dunia, pengajaran Alquran juga secara otomatis mulai tersebar mengikuti penyebaran Islam. ${ }^{12}$ Hampir di setiap tempat yang berpenduduk muslim, terdapat lembaga pendidikan yang khusus mengajarkan baca-tulis Alquran

8 al-Tirmiżi, Sunan al-Tirmiżi, "Kitāb Faḍāil al-Qurān 'an Rasūlillāh", no. 2835, CD Software Mausūah al-Hadīs al-Syarîf.

9 Muslim, Șaḥị̣ Muslim, "Kitāb Șalātu al-Musāfirīn wa Qașrihā", no. 1329, CD Software Mausūah al-Hadīs al-Syarîf.

10 Muslim, Șahịh Muslim, "Kitāb Șālātu al-Musāfirīn", no. 1337

11 al-Bukhāri, Șaḥị̣ al-Bukhāri, "Kitāb Faọāil al-Qur'ān", no. 4639, CD Software Mausūàh al-Hadīs al-Syarîf.

12 Pada masa ini para sahabat mengajarkan Alqurankepada umat Islam yang ada di daerahnya, seperti Abdullah bin Mas'ud, Zaid bin Tsabit, dan Abu Musa Al-Asy’ary. Pada perkembangkan selanjutnya, para tabi'in yang telah belajar Alqurankepada para sahabat melanjutkan estafet pengajaran Alqurandi berbagai wilayah. Di Bashrah misalnya ada Ibnu Sirin dan Qatadah, di Kufah ada Alqamah dan Masruq, dan di wilayah Syam ada al-Mughirah bin Abi Syihab. Dari beberapa wilayah ini juga kemudian lahir para imam qiräat masyhūrah. Lihat Al-Zarqani, Manāhil al-'Urfān (Beirut: Dār al-Kutub al'Ilmiyyah, 1996), Juz I, hlm. 412. 
kepada anak-anak. Beberapa lembaga pendidikan tinggi di penjuru dunia juga membuka program studi yang khusus mempelajari Alquran. Berbagai diskusi yang berawal dari pembacaan Alqurandiadakan di berbagai kesempatan untuk mendapatkan ilmu pengetahuan dan petunjuk yang ada di dalamnya. Dengan belajar Alquran, selain dapat membaca teks Alquran, pada tahap lanjut seorang muslim juga dapat memahami pesan-pesan yang ada di dalamnya.

\section{B. Resepsi Fungsional terhadap Alquran}

Pemahaman terhadap pesan-pesan Alquran kemudian dapat difungsikan sebagai petunjuk berperilaku dalam kehidupan di dunia. Jika Alquran diposisikan sebagaimana fungsi tersebut, ia dibaca, dipahami, dan dipraktikkan sesuai dengan makna yang terkandung di dalam teksnya. Akan tetapi di sisi lain juga ditemukan berbagai pembacaan Alquran yang dibaca dan dipraktikkan di luar makna tekstualnya. Āyat Kursi misalnya, ia adalah salah satu ayat yang banyak dihafal oleh umat Islam, ia sering dibaca dalam beberapa kesempatan karena dipandang mampu melindungi diri dari segala gangguan terutama dari yang bersifat gaib. ${ }^{13}$ Dalam konteks ini, S.H. Nasr menjelaskan bahwa ayat-ayat Alquran dianggap mengandung kekuatan magi, ia menyerupai azimat yang dapat melindungi manusia. ${ }^{14}$ Dengan kekuatan yang dimiliki tersebut, Alquran dibaca untuk berbagai tujuan yang bersifat praktis dan dianggap mampu memberikan keuntungan bagi pembacanya.

Praktik semacam ini juga ternyata ditemukan riwayatnya di berbagai literatur klasik, terutama di dalam kitab-kitab hadis. Di dalam kitab hadis mu'tabarah seperti Șaḥị̣ al-Bukhāri, Șaḥị̣ Muslim, dan Sunan Ibnu Mājah terdapat satu bab yang diberi nama Faḍail al-Qurān. Bab ini berisi riwayat-riwayat tentang keutamaan Alquran, mulai dari sikap yang seharusnya dimiliki seseorang terhadap Alquran

13 Ingrid Mattson, Ulumul Quran Zaman Kita, hlm. 235.

14 S.H. Nasr, Islam dalam Cita dan Fakta (Jakarta: LAPPENAS, 1981), hlm. 28. 
sampai berbagai keuntungan yang akan diperoleh jika membaca ayat atau surat tertentu. Beberapa riwayatnya, bahkan yang memiliki kualitas Șaḥị̣ menunjukkan bahwa, praktik pembacaan Alqura nuntuk tujuan tertentu di luar konteks ibadah juga telah dilakukan oleh Nabi Muhammad.

Selain di dalam kitab-kitab hadis mu'tabarah, riwayat tentang praktik pembacaan Alquran untuk tujuan tertentu juga terdapat di dalam beberapa karya yang secara khusus menampilkan riwayatriwayat tersebut. Di antara karya-karya tersebut adalah kitab Faḍāil al-Qur'ān karya Ibn al-Ḍurais, al-Nasāì, al-Qāsim bin Salām, al-Firyābi, dan al-Mustaghfiri. Al-Qurțubi juga menyusun kitab senada dengan judul Al-Tiżkār fi Afḍali al-Ażkār. Kitab ini juga berisi hadis-hadis tentang keutamaan Alquran dan fa dīlah yang dimiliki oleh surat dan ayat-ayatnya. Di dalam kitab Al-Tibyān fi Adabi Hamalati al-Qur'ān, al-Nawāwi juga secara khusus menyajikan riwayat-riwayat tentang surat-surat Alquran yang dibaca pada waktu tertentu. Di dalamnya, ia menampilkan riwayat-riwayat tentang keuntungan dan khasiat yang dimilki oleh surat atau ayat Alquran bagi pembacanya. Dari beberapa literatur tersebut, secara umum praktik pembacaan Alquran untuk tujuan tertentu pada masa lalu dapat diklasifikasikan ke dalam beberapa kategori:

\section{Untuk Pengobatan}

Di dalam kitab al-Tibyān, pada sub bab yang diberi judul " $f \bar{i}$ mā yuqra'u 'inda al-marīọi', al-Nawāwi menjelaskan bahwa ketika seseorang sedang sakit sunnah dibacakan Surat al-Fātiḥaḥ, al-Ikhlāṣ, dan al-Mu'awwiżatain ${ }^{15}$.

15 Nama lain untuk menyebut surat al-Falaq dan al-Nās. Nama itu diambil dari dari kata a'üżu yang terdapat di dalam kedua surat tersebut, sehingga disebut sebagai al-Mu'awwiżatain yang artinya dua surat yang menuntun pembacanya kepada tempat perlindungan atau memasukkannya ke dalam tempat yang dilindungi. Dari nama tersebut, para ulama memberi nama surah al-Falaq dengan al-Mu'awwiżah al-ūla, sedangkan surat al-Nās dengan al-Mu'awwiżah al-s̄äniyah. Lihat M. Quraish Shihab, Tafsir al-Misbah: Pesan, Kesan dan Keserasian Alquran(Jakarta: Lentera Hati, 2007) 


$$
\begin{aligned}
& \text { يستحب أن يقرأ عند المريض بالفاتحة لقوله صلى الله عليه وسلم: في الحميث } \\
& \text { الصحيح فيها وما أدراك أهما رقية * ويستحب أن يقرأ عنده قل هو الله أحد } \\
& \text { وقل أعوذ برب الفلق وقل أعوذ برب الناس مع النفث في اليدين } 16
\end{aligned}
$$

Artinya: Sunnah membaca al-Fātihạạ di samping orang sakit berdasarkan sabda Nabi saw dalam hadits sahih yang di dalamnya terdapat perkataan: "Dari mana engkau tahu bahwa di dalam Al-Fātiḥạ̣ terdapat ruqyah (sejenis obat dan mantra)?” Dan sunnah membaca Qul huwallāhu aḥad, Qul a'üżu bi rabbi al-falaq dan Qul a'üżu bi rabbi al-nās untuk orang sakit dengan meniup kedua telapak tangan.

Di dalam keterangan tersebut al-Nawāwi menjelaskan bahwa pembacaan Surat al-Fātiḥạ̣ terhadap orang yang sakit didasarkan pada hadis tentang ruqyah yang dilakukan oleh salah seorang sahabat nabi kepada seorang penduduk perkampungan yang terkena sengatan hewan berbisa. Hadis ini bersumber dari riwayat Șaḥi ḥ yang di-takhrij oleh al-Bukhāri di dalam beberapa bab dalam al-Jāmi'-nya.

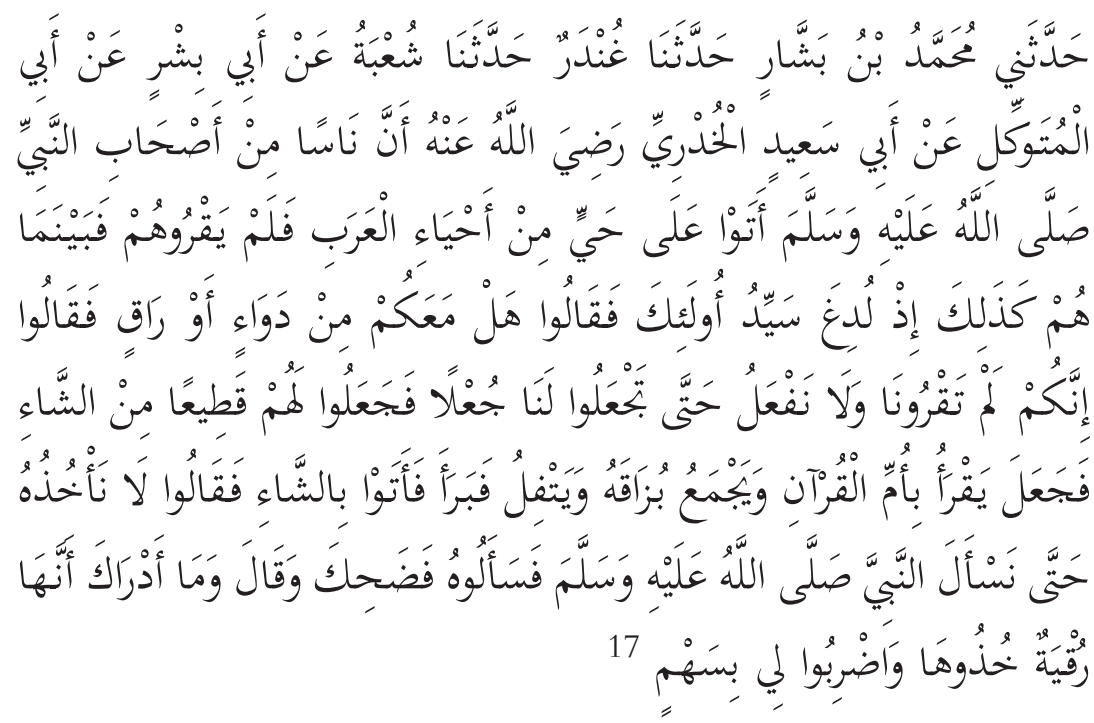

16 al-Nawāwi, al-Tibyān fi Adabi Hamalati al-Qurān (Surabaya: Al-Hidayah, t.th), hlm. 145. 17 al-Bukhāri, Șaḥị̣ al-Bukhāri, "Kitāb al-Ṭibb”, no. 5295, CD Software Mausūiah al-Hadīs al-Syarîf. Para sahabat meriwayatkan peristiwa ini secara maknawi, sehingga selain redaksi ini terdapat redaksi lain yang diriwayatkan oleh para sahabat dan telah di-takhrij 
(Telah menceritakan kepadaku Muhammad bin Basyar telah menceritakan kepada kami Ghundar telah menceritakan kepada kami Syu'bah dari Abu Bisyr dari Abu al-Mutawakkil dari Abu Sa'īd al-Khudri radliallahu 'anhu bahwa beberapa orang sahabat Nabi shallallahu 'alaihi wasallam mengadakan suatu perjalanan, ketika mereka melewati salah satu perkampungan dari perkampungan Arab, orang-orang kampung tersebut tidak menerima mereka, ketika sikap mereka masih seperti itu seorang pemimpin mereka terkena sengatan kalajengking, lalu mereka pun berkata; "Apakah di antara kalian ada yang mempunyai obat, atau seorang yang bisa me-ruqyah?" lalu para sahabat Nabi pun berkata; "Sesungguhnya kalian tidak mau menerima kami, maka kamipun tidak akan melakukannya sehingga kalian memberikan imbalan kepada kami, " akhirnya mereka pun berjanji akan memberikan beberapa ekor kambing."Lalu seorang sahabat Nabi membaca Ummul Qur`an dan mengumpulkan ludahnya seraya meludahkan kepadanya hingga laki-laki itu sembuh, kemudian orang-orang kampung itu memberikan kepada para sahabat Nabi beberapa ekor kambing." Namun para sahabat Nabi berkata; "Kita tidak akan mengambilnya hingga kita bertanya kepada Rasulullah shallallahu 'alaihi wasallam tentang hal ini, "lalu mereka bertanya kepada Nabi shallallahu 'alaihi wasallam tentang pemberian itu hingga membuat beliau tertawa. Beliau bersabda: "Tidak tahukah bahwa itu ruqyah, ambillah pemberian tersebut dan berilah bagiannya untukku.")

Selain al-Fātị̣aḥ, dalam penjelasan al-Nawāwi di atas, ia menambahkan bahwa orang yang sakit, sunnah dibacakan Surat alIkhlāṣ dan al-Mu'awwiżatain dengan cara meniupkan bacaan tersebut pada kedua telapak tangan. Keterangan ini juga bersumber pada riwayat hadis Șaḥi ḥ yang diriwayatkan oleh Aisyah.

oleh para ulama' hadis. Di dalam Șahịḥ al-Bukhāri sendiri, selain terdapat di dalam bab pengobatan, hadi ini juga ditemukan di dalam "Kitāb al-Ijārah", no. 2115, "Kitāb Faḍāil al-Qurāan", no. 4622 dan 4623. Hadis ini juga ditakhrij oleh Muslim, Șaḥị̣ Muslim, "Kitab al-Salām", no. 4080 dan 4081; al-Tirmizii, Sunan al-Tirmiżi, "Kitāb al-Ṭibb 'an Rasūlillāh", no. 1989; Abu Dawud, Sunan Abi Dāwūd, "Kitāb al-Buyū"', no. 2965 dan "Kitāb al-Ṭibb", no. 3401; Ibnu Majah, Sunan Ibn Mājah, "al-Tijärah", no. 2147; Ahmad, Musnad A ḥmad, "Bāqi Musnad al-Mukaśṡirīn", no. 10562, 10648, 10972, 11046, 112361. 


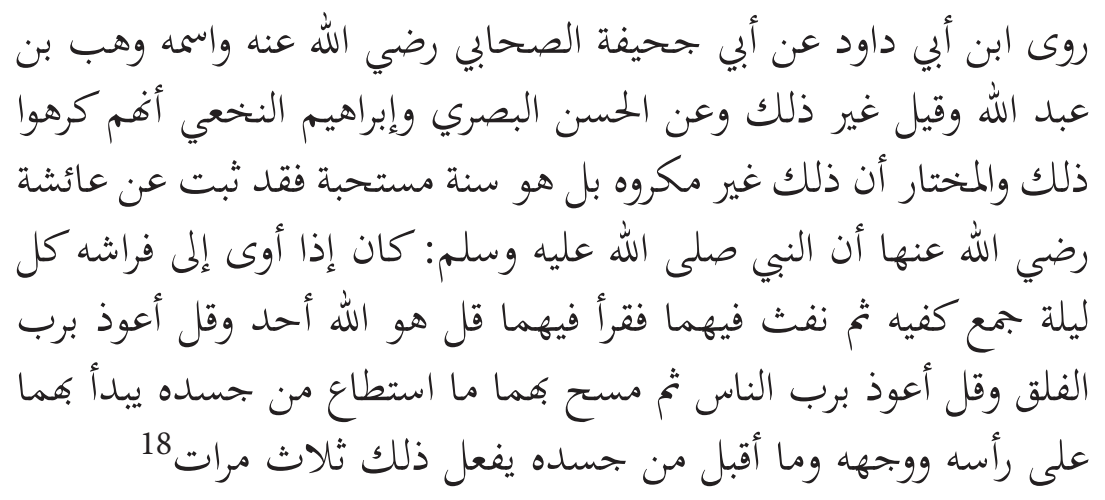

Diriwayatkan oleh Ibnu Abi Dāwūd dari Abu Juhaifah seorang sahabat Nabi saw yang bernama Wahb bin Abdullah - atau ada yang mengatakan bukan dia - dari Ḥasan Al-Bașri dan Ibrahim Al-Nakhāi bahwa mereka tidak menyukai itu. Pendapat yang terpilih adalah tidak makruh, bahkan sunnah muakkad. Diriwayatkan dari 'Aisyah ra: "Bahwa Nabi saw apabila hendak tidur setiap malam, beliau merapatkan kedua telapak tangannya, kemudian meniup pada keduanya, kemudian membaca 'Qul huwallāhu ahad, Qul a'ūdzu bi rabbil falaq dan Qul a'üżu bi rabbi al-nās. Kemudian beliau sapukan keduanya pada tubuhnya sedapat mungkin dimulai dari atas kepala dan mukanya serta bagian tubuhnya yang dapat dicapai. Beliau melakukan hal itu tiga kali.

Di dalam al-Tibyān, al-Nawāwi menambahkan riwayat yang menerangkan ketika Nabi sakit, beliau juga melakukan hal yang sama. Menurut pengakuan 'Aisyah dalam beberapa riwayat, ketika sakit Nabi bertambah parah, ia yang membacakan al-Mu'awwiżatain dan melakukannya sebagaimana yang dilakukan oleh Nabi pada riwayat di atas. ${ }^{19}$ Dari redaksi hadis di atas, al-Nawāwi kemudian meletakkan Surat al-Fātiḥaḥ ${ }^{20}$, al-Ikhlāṣ, dan al-Mu'awwiżatain ke dalam sub bab

18 al-Nawāwi, Al-Tibyān fi Adabi Hamalati al-Qur'ān, hlm. 138. Hadis ini bersumber dari riwayat al-Bukhāri, Șaḥīh al-Bukhāri, "Kitāb Faḍāil al-Qurān", no. 4630.

19 al-Nawāwi, Al-Tibyān fi Adabi Hamalati al-Qur'ān, "Faśl Fi al-Nafaśi ma'a al-Qurān li al-Ruqyah", hlm. 138. Riwayat ini bersumber dari al-Bukhāri, Șaḥīh al-Bukhāri, "Kitāb Faḍāil al-Qurān", no. 4629; Muslim, Șaḥị̣ Muslim, "Kitāb al-Salām", no. 4066; Abu Dāwūd, Sunan Abi Dāwūd, "Kitāb al-Ṭibb", no. 3403; Ibnu Mājah, Sunan Ibn Mājah, "Kitāb al-Ṭibb", no. 3520; Ạ̣mad, Musnad Aḥmad, "Baqiya Musnad al-Anshāri", no. 23585, 23687, 24993, 25062; Mālik, Muwațța', “al-Jāmi”, no. 1480.

20 Di dalam kitab-kitab Façāil al-Qurān, riwayat seperti ini dimasukkan ke dalam bab 
bacaan Alquran yang dibacakan kepada orang yang sakit. Judul bab yang diberikan oleh al-Nawāwi ini menunjukkan bahwa ayat-ayat Alquran memiliki keutamaan yang secara fungsional dapat digunakan sebagai pengobatan.

Pemberian judul yang bersifat fungsional tersebut juga terdapat di dalam Faḍàil al-Qur'ān karya al-Mustaghfiri. Salah satu riwayat tentang keutamaan surat al-Baqarah diletakkan pada sub bab yang diberi judul Mațlabu mā Yuqráu 'alà al-Majnūni. Dari judul tersebut, pembaca tentu akan mengira bahwa riwayat-riwayat yang akan ditampilkan di dalam sub bab tersebut berisi petunjuk untuk menyembuhkan orang gila.

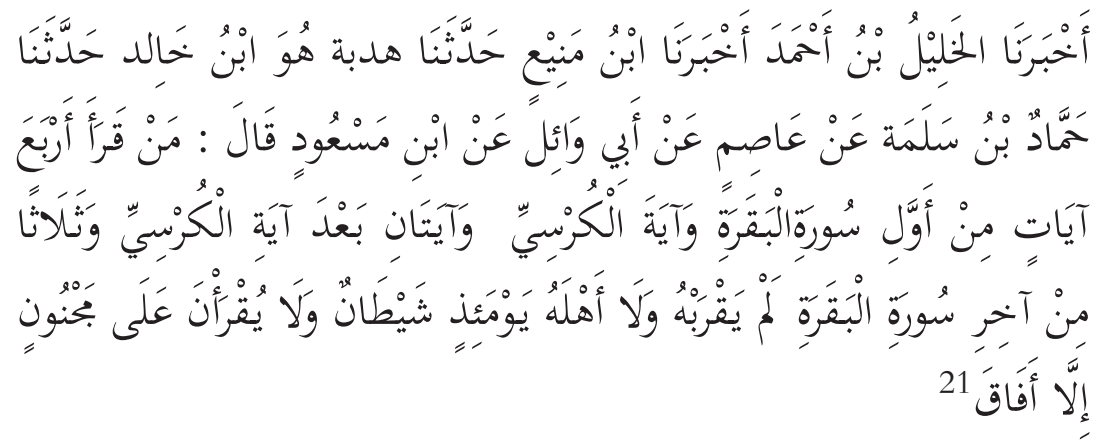

Telah mengabarkan kepada kami al-Khalīl bin Ahmad, telah mengabarkan kepada kami Ibnu Māni', telah meriwayatkan kepada kami Hadabah yaitu Ibnu Khālid, telah meriwayatkan kepada kami Ḥammād bin Salāmah dari 'Āṣim dari Abū Wảil dari Ibnu Mas'ūd, ia berkata: Barangsiapa yang membaca empat ayat dari awal surat alBaqarah, Áyat Kursi, dua ayat setelahnya dan tiga ayat terakhir dari surat al-Baqarah, maka tidak ada satu setan pun yang mendekati dirinya dan keluarganya pada hari itu, serta tidak ada pula sesuatu pun yang ia

Faḍilah Fātihatu al-Kitāb. Di antaranya terdapat di dalam al-Qurțubi, al-Tiżkār fi Afọali al-Ażkār (Damaskus: Maktabah Dār al-Bayān, 1987), hlm. 229 dan al-Qāsim bin Salām, Faḍāil al-Qurān wa Mảālimuhu wa Adābuhu (t.k: Al-Maktabah Al-Gharbiyyah, 1995), no. 408 , hlm. 28.

21 al-Mustaghfiri, Façāil al-Qurān, "Mațlabu Mā Yuqra’u 'alā al-Majnūn” (Beirut: Dar Ibnu Hazm, 2006), no. 1135, hlm. 762. Riwayat ini juga terdapat di dalam al-Durais, Facōail alQurān wa mā Unzila min al-Qurān bi Makkah wa mā Unzila bi al-Madīnah (Beirut: Dar al-Fikr, 1987), hlm. 84. Redaksi riwayat ini tetapi dengan jalur yang berbeda terdapat di dalam al-Dārimi, Sunan al-Dārimi, "Kitāb Fa dạil al-Qurān", no. 3249. 
benci (mendatangkan madharat baginya). Tidaklah dibacakan ayat-ayat tersebut kepada orang gila, kecuali ia pasti sadar.

Tidak seperti riwayat sebelumnya, riwayat ini termasuk hadis mauqūf yang hanya sampai kepada sahabat. Meski demikian, hal ini menunjukkan bahwa praktik pembacaan secara fungsional sudah dilakukan sejak masa awal Islam, bahkan semakin meluas setelah Nabi wafat. ${ }^{22}$ Keluasan praktik ini dapat dilihat dari riwayat-riwayat tentang keutamaan membaca ayat atau surat tertentu di dalam Alquran yang dikatakan atau dilakukan oleh para sahabat dan generasi setelahnya. Diantaranya sebagaimana yang terdapat di dalam al-Tiżkār, al-Qurțubi menyebutkan keterangan dari al-Ṡa'labi bahwa Surat al-An'ām ayat 67 dapat menyembuhkan sakit gigi. Di dalam riwayat ini, ia juga menjelaskan tata cara penggunaan ayat tersebut agar dapat digunakan sebagai obat sakit gigi.

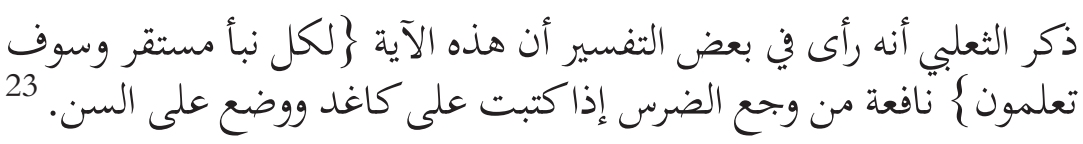

Al-Ṡa'labi menyebutkan bahwa ia membaca dalam sebagian tafsir bahwa ayat ini "untuk tiap-tiap berita (yang dibawa oleh Rasul-rasul) ada waktu terjadinya dan kelak kamu akan mengetahui." Berguna bagi orang yang sakit gigi apabila ditulis pada kertas lalu diletakkan pada gigi yang sakit.

\section{Untuk Melindungi diri dari Makhluk Ghaib}

Selain digunakan sebagai pengobatan, pembacaan Alquran juga digunakan sebagai salah satu cara untuk melindungi diri dari gangguan makhluk gaib. Petunjuk ini dapat ditemukan di dalam literatur hadis mu'tabarah yang kemudian dirujuk oleh para penyusun kitab Façāil al-Qur'ān. Salah satu di antaranya terdapat di dalam kitab Façāil alQur'ān karya al-Firyābi.

22 Riwayat tentang keutamaan surat-surat Alquran yang sampai kepada Nabi sebagian besar hanya disampaikan secara umum. Riwayat-riwayat yang menjelaskan tentang keutamaan atau keuntungan secara fungsional yang akan diperoleh pembaca jika membaca ayat atau surat tertentu juga relatif lebih sedikit jika dibandingkan dengan riwayat yang hanya sampai kepada para sahabat. Lihat Ahmad Rafiq, "Faḍāil al-Qurān", hlm. 59.

23 al-Qurțubi, al-Tiżkār fì Af̣̣ali al-Ażkār, hlm. 256. 


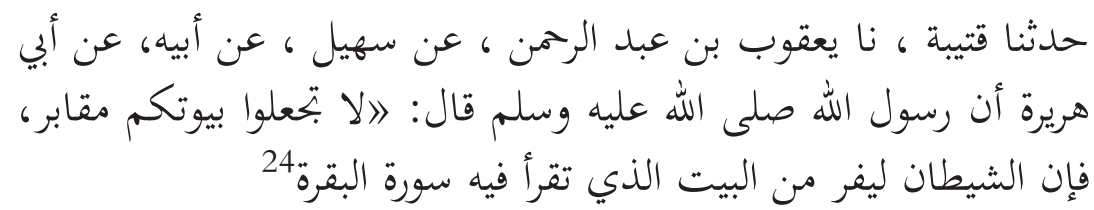

Telah menceritakan kepada kami Qutaibah bin Sa'īd telah menceritakan kepada kami Ya’qūb bin 'Abdurrahmān al-Qari dari Suhail dari bapaknya dari Abū Hurairah bahwa Rasulullah shallallahu 'alaihi wasallam bersabda: "Janganlah kalian jadikan rumah-rumah kalian sebagai kuburan, sesungguhnya setan itu akan lari dari rumah yang di dalamnya dibacakan surat al-Baqarah."

Riwayat yang disampaikan langsung oleh Nabi ini secara eksplisit menunjukkan bahwa rumah yang dibacakan surat al-Baqarah tidak akan didekati oleh makhluk gaib yaitu setan. Ini merupakan salah satu keuntungan yang dapat diperoleh di dunia oleh pembaca surat al-Baqarah. Selain riwayat di atas, di dalam kitab Șahīh al-Bukhāri terdapat riwayat yang menceritakan tentang pengalaman yang dialami oleh sahabat terkait dengan keutamaan ayat yang ada di dalam surat al-Baqarah, yaitu Āyat Kursi.

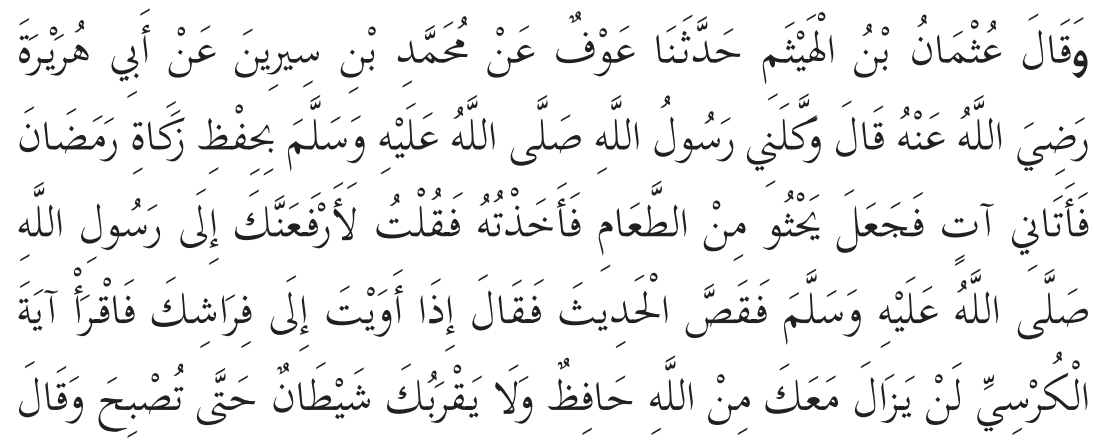

24 al-Firyābi, Façāil al-Qur'ān wa mā Jā̉a fìhi min al-Faọlli wa fì Kam Yuqra' wa al-Sunnah fi żālika (Riyāọ: Maktabah al-Rusyd, 1989), hlm. 147. Riwayat ini bersumber dari hadis yang diriwayatkan oleh Muslim, Șaḥị Ṃ Muslim, "Kitab Șalātu al-Musāfirīn wa Qașrihā", no. 1300. Riwayat yang sama juga ditemukan di dalam al-Nasāi, Faḍāil al-Qurān (Beirut: Dār Iṇyā' al-'Ulūm, 1996), hlm. 90. Diriwayatkan dengan redaksi dan jalur yang berbeda di dalam al-Qāsim bin Salam, Faḍāil al-Qurān wa Maālimuhu wa Adābuhu, hlm. 32; juga terdapat di dalam di dalam al-Durais, Façāil al-Qurān wa mā Unzila min al-Qurān bi Makkah wa mā Unzila bi al-Madīnah (Beirut: Dār al-Fikr, 1987), hlm. 84. Redaksi riwayat ini tetapi dengan jalur yang berbeda terdapat di dalam al-Dārimi, Sunan al-Dārimi, "Kitāb Faụāil al-Qurān”’, no. 3249. 


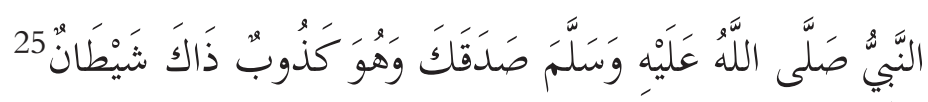

Uṡmān bin al-Hais̀am berkata; Telah menceritakan kepada kami 'Áuf dari Muhammad bin Sīrīn dari Abū Hurairah radliallahu 'anhu, ia berkata; Rasulullah shallallahu 'alaihi wasallam menugaskanku untuk menjaga harta zakat. Lalu pada suatu hari ada seseorang yang menyusup hendak mengambil makanan, maka aku pun menyergapnya seraya berkata, "Aku benar-benar akan menyerahkanmu kepada Rasulullah shallallahu 'alaihi wasallam.." lalu ia bercerita dan berkata, "Jika kamu hendak beranjak ke tempat tidur maka bacalah Āyat Kursi, niscaya Allah akan senantiasa menjagamu dan setan tidak akan mendekatimu hingga pagi." Maka Nabi shallallahu 'alaihi wasallam pun bersabda: "Ia telah berkata benar padamu, padahal ia adalah pendusta. Si penyusup tadi sebenarnya adalah setan."

Selain dapat melindungi diri dari gangguan setan, ayat Alquran juga dapat digunakan untuk melindungi diri dari kekuatan sihir. Riwayat ini disampaikan oleh sahabat Ibnu Abbas sebagaimana yang dikutip oleh al-Qurțubi di dalam al-Tiżkār.

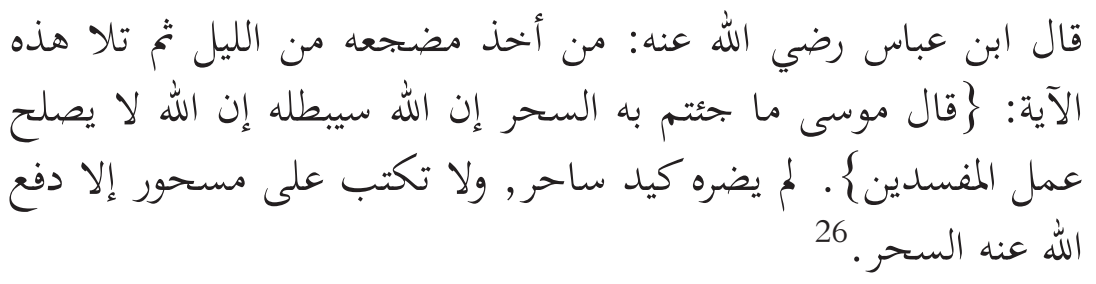

Ibnu 'Abbās ra. berkata: Barangsiapa yang berbaring hendak tidur pada malam hari, kemudian ia membaca ayat ini "Maka setelah mereka lemparkan, Mūsa berkata: "Apa yang kamu lakukan itu, itulah yang sihir, sesungguhnya Allah akan menampakkan ketidak benarannya". Sesungguhnya Allah tidak akan membiarkan terus berlangsungnya pekerjaan orang-orang yang membuat kerusakan." Maka tipu daya sihir tidak akan membahayakannya, Allah akan menolak sihir yang dikirimkan kepadanya.

25 al-Bukhari, Śaḥị̣ al-Bukhāri, "Faḍāil al-Qur'ān", no. 4624.

26 al-Qurțubi, al-Tiżkār fi Afọali al-Ażkār, hlm. 257. 


\section{Untuk Mengatasi Persoalan Ekonomi}

Salah satu riwayat hadis yang sampai saat ini masih memiliki pengaruh terhadap persepsi umat Islam adalah riwayat tentang keutamaan membaca surat al-Wāqiah. Surat yang secara tekstual isinya mengabarkan tentang hari kiamat ini dianggap mampu mencegah datangnya kemiskinan.

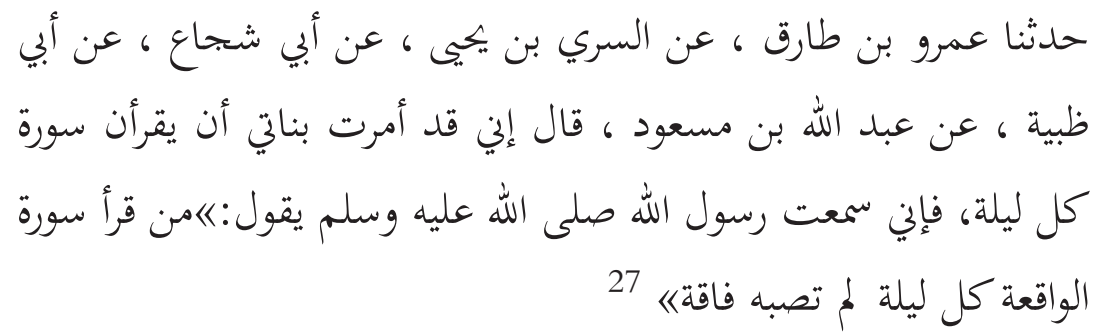

Telah meriwayatkan kepada kami 'Amr bin Ṭāriq dari al-Sirri bin Yaḥya dari Abu Syujä’ dari Abu Zabiyyah dari Abdullah bin Mas'ūd, ia berkata: Sungguh aku memerintahkan kepada anak-anak perempuanku untuk membaca Surat al-Wāqiah setiap malam, karena sesungguhnya aku telah mendengar Rasulullah saw. bersabda: "Barangsiapa membaca Surat alWāqiah setiap malam maka kefakiran tidak akan menimpanya.”

Kualitas riwayat ini sebenarnya tidak masuk dalam kategori hadis maqbūl, karena menurut keterangan al-Qāsim, perawi riwayat ini ada yang majhūl. Ahmad bin Hanbal juga berkomentar bahwa riwayat ini munkar. Riwayat ini juga ternyata tidak ditemukan di dalam kitab-kitab hadis mu'tabarah yang secara primer dijadikan rujukan. Riwayat tersebut ditemukan di dalam kitab-kitab hadis antologi dan kitab-kitab Faḍāil al-Qur'ān. Meski demikian, riwayat ini populer di kalangan umat Islam dan diresepsi oleh mereka di dalam berbagai momen kehidupan mereka. Di dalam riwayat tersebut, Abdullah bin Mas'ūd telah merespon perkataan yang disandarkan kepada Nabi. Ia

27 al-Qāsim bin Salām, Façāil al-Qurān wa Mààlimuhu wa Adābuhu, hlm. 67. Riwayat ini juga ditemukan di dalam al-Nawāwi, al-Ażkār, Tilāwah al-Qurān, No. 323 (Beirut: Dār al-Fikr, 1994), hlm. 111; Ibnu Ḥajar al-'Asqalāni, al-Mațlab al-Āliyah (Beirut: Dār alKutub al-'Ilmiyyah, 2003) Juz VIII, hlm. 286; al-Baihaqi, Syu’bu al-İmān (Beirut: Dār alKutub al-'Ilmiyyah, 2000), II, hlm. 491; al-Ḍurais, Façāil al-Qur'ān, hlm. 103; al-Qurțubi, al-Tiżkär fi Afọali al-Ażkār, hlm. 287; 
memerintahkan anak-anaknya untuk membaca al-Wāqiah di setiap malam agar terhindar dari kemiskinan.

Selain surat al-Wāqiah, ada riwayat lain yang mengatakan bahwa surat al-Ikhlāș yang disebut sebagai sepertiga Alquran dapat mencegah kefakiran orang yang membacanya. Bukan hanya itu, tetangga di lingkungan sekitarnnya juga mendapat keuntungan tersebut. Seperti halnya riwayat tentang keutamaan membaca Surat al-Wāqi'ah, riwayat ini juga hanya ditemukan pada kitab-kitab hadis sekunder dan sebagian kitab Faḍāil. Salah satunya, sebagaimana yang terdapat di dalam Makārim al-Akhlāq:

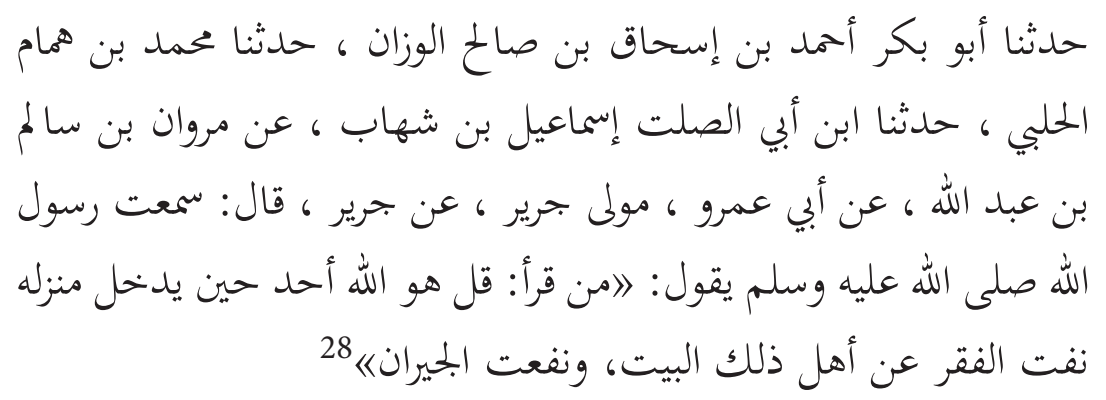

Telah meriwayatkan kepada kami, Abu Bakar Ahmad bin Ishāq bin Sāliḥ, telah meriwayatkan kepada kami Muhammad bin Hammam, telah meriwayatkan kepada kami Ismail bin Syihāb dari Marwān bin Sālim bin 'Abdillah dari Abu Umar, pembantu Jarir, dari Jarir ia berkata: Aku telah mendengar Rasulullah saw. bersabda: "Barangsiapa membaca Qul Huwallāhu A had ketika masuk rumahnya, maka kefakiran tidak akan menimpa penghuni rumah itu beserta tetangganya."

Di dalam kitabnya tersebut, al-Kharāiți meletakkan riwayat tersebut di dalam bab hal yang disunnahkan bagi seseorang ketika memasuki rumahnya. Padahal secara tekstual, ayat-ayat yang terdapat

28 al-Kharāiți, Makārim al-Akhlāq (t.k: t.p, 2000), CD Software al-Marja' al-Akbar li Turāś al-Islāmi, Vers. 3.0. Riwayat ini juga terdapat di dalam al-Hais̀ami, Majma' al-Zawāid (Beirut: Dār al-Fikr, 1994), Juz 10, hlm. 179. al-Haiṡami mengatakan bahwa Marwān bin Sālim adalah perawi yang matrūk; al-Suyūți, Jāmi' al-Masānid wa al-Marāsil (Beirut: Dār al-Fikr, 1994), Juz 7, hlm. 342; al-Ṭabrāni, Mu’jam al-Ṭabrāni al-Kabīr (t.k: Mațba’ah al-Zahrä al-Hadasंiyyah, t.th), Juz 2, hlm. 340; dan al-Hasan Muhammad bin al-Khilal, Faḍāil Surah al-Ikhlāș, CD Software al-Marja’ al-Akbar li Turāś al-Islāmi, Vers. 3.0. 
di dalam Surat al-Ikhlāṣ adalah ayat-ayat tentang ketauhidan. Surat ini sama sekali tidak berbicara tentang persoalan ekonomi. Tetapi kemudian, berdasarkan riwayat yang disandarkan kepada Nabi tersebut, ayat ini direspon oleh penyusun kitab hadis semisal alKharāiți dan al-Haiṡami sebagai petunjuk ketika memasuki rumah.

Pada riwayat lain sebagaimana yang dikutip oleh al-Qurțubi dari riwayat al-Țabrani dijelaskan bahwa ada seseorang yang datang kepada nabi dan mengadu tentang kefakiran dan kesulitan untuk mencari nafkah. Kemudian Nabi saw. memerintahkannya untuk mengucapkan salam ketika memasuki rumah, jika tidak ada orang maka Nabi memerintahkan untuk mengucapkan salam untuk beliau dan membaca Surat al-Ikhlāș. Diceritakan di dalam riwayat itu bahwa setelah ia mengerjakannya, Allah memberikan rizki yang melimpah untuknya dan tetangganya. ${ }^{29}$

\section{Untuk Memudahkan Urusan}

\section{a. Kemudahan ketika Sakaratul Maut}

Surat Yāsīn merupakan salah satu surat yang populer di kalangan masyarakat muslim. Surat yang disebut sebagai Qalbu al-Qur'ān $n^{30}$ ini biasanya dibacakan untuk orang yang sedang menghadapi sakaratul maut ${ }^{31}$ atau setelah meninggal. Terkait dengan hal ini, terdapat riwayat hadis yang menjelaskan praktik tersebut.

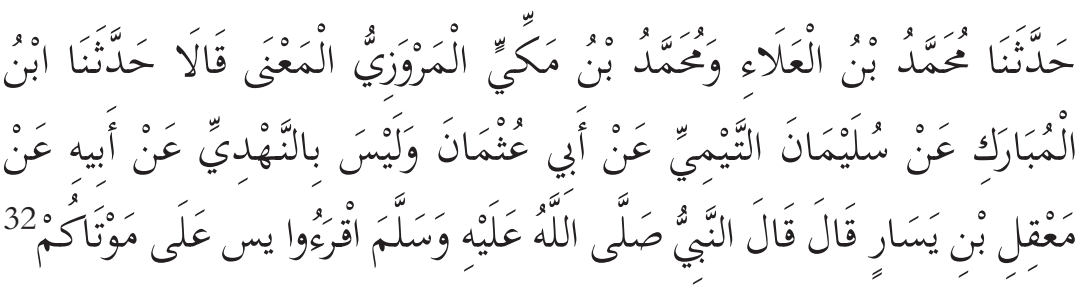

29 al-Qurțubi, al-Tiżkār fi Afọali al-Ażkār, hlm. 300.

30 Disebutkan di dalam al-Tirmiżi, Sunan al-Tirmiżi, "Kitāb Faḍāil al-Qurān 'an Rasūlillāh", no. 2812. Diriwayatkan juga di dalam al-Dārimi, Sunan al-Dārimi, "Kitab Faḍāil alQư’ān”, no. 3282.

31 Keadaan ketika seseorang telah lemah (tidak sadar atau setengah sadar) yang menunjukkab bahwa dia (akan menjadi) mayit. Lihat Ibnu Manḍūr, Lisān al-'Arab (Beirut: Dar al-Fikr, 1993).

32 Abū Dāwūd, Sunan Abi Dāwūd, "Kitāb al-Janāiz", no. 2714; riwayat ini juga terdapat di 
Telah menceritakan kepada kami Muhammad bin al-'Alā', dan Muhammad bin Makki Al Marwazi, secara makna, mereka berkata; telah menceritakan kepada kami Ibnu al-Mubārak dari Sulaimān al-Taimi dari Abū 'Uśmān bukan al- Nahdi, dari ayahnya, dari Ma’qil bin Yasār, ia berkata; Nabi shallallahu 'alaihi wasallam bersabda: "Bacakanlah Surat Yāsīn kepada orang yang akan meninggal diantara kalian.”

Di dalam riwayat lain dijelaskan bahwa mayit yang dibacakan Surat Yāsīn akan diberikan kemudahan ketika melalui sakaratul maut. ${ }^{33}$ Oleh karena keutamaan ini, meski kualitasnya dinilai ḍa îff, al-Nawāwi menempatkan riwayat ini di dalam al-Tibyān dengan judul fī mā yuqra 'u 'inda al-Mayyiti. ${ }^{34}$ Bahkan, ia menerangkan bahwa membaca Surat Yāsīn untuk mayit adalah perbuatan yang disunnahkan. ${ }^{35}$

\section{b. Kemudahan ketika Melahirkan Anak}

Sebagaimana keterangan-keteragan sebelumnya, Alquran memiliki keutamaan yang sangat luas. Ayat-ayatnya dapat diresepsi untuk mengatasi berbagai urusan. Di dalam riwayat berikut ini, ayatayat Alquran dibacakan untuk perempuan yang sulit melahirkan.

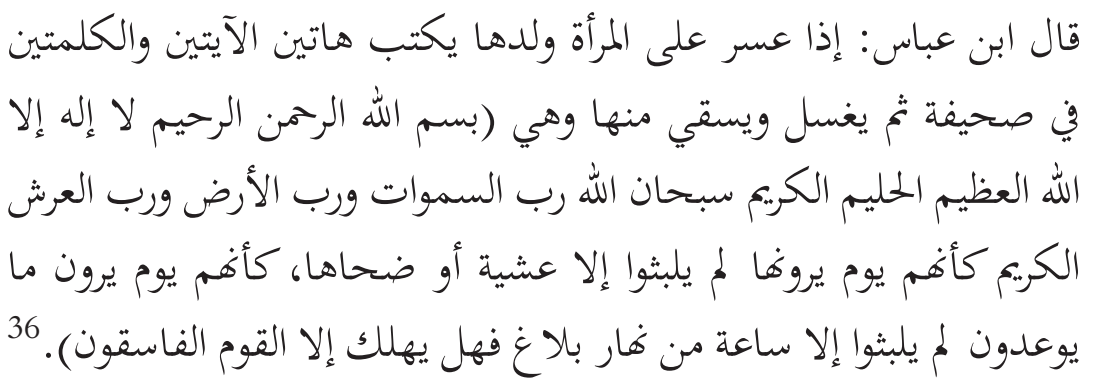

dalam Ibnu Mājah, Sunan Ibnu Mājah, no. 1438; Aḥmad, Musand Aḥmad, "Awwalu Musnad al-Bașriyyin", no 19415 dan 19427; al-Qurțubi, al-Tiżkr fi Afọali al-Ażkār, hlm. 273; al-Qāsim bin Salām, Fac̣āil al-Qurān wa Mảālimuhu wa Adābuhu, hlm. 63.

33 al-Qurțubi, al-Tiżkār fī Afọali al-Ażkār, hlm. 273

34 Hal ini juga dilakukan oleh Abū Dāwud dan Ibnu Mājah. Di dalam Sunan-nya, Abu

Dāwud meletakkan riwayat ini di dalam bab "al-Qirāah 'inda al-Mayyiti". Sedangkan

Ibnu Mājah meletakkan riwayat ini dalam bab "mā jảa fĩ mā Yuqālu 'inda al-Marīọi iża Ḥaḍara". Sedangkan pada bab tentang yang dibaca untuk jenazah, ia menampilkan riwayat bahwa nabi membacakan Surat al-Fātiḥaḥ untuk mayyit. Lihat Ibnu Mājah, Sunan Ibnu Mājah, "Kitab mā jāa fi al-Janāiz", no. 1484 dan 1485.

35 al-Nawāwi, al-Tibyān fì Adabi Hamalati al-Qurān, hlm. 146

36 al-Qurțubi, al-Tiżkār fì Afọali al-Ażkār, hlm. 284. 
Ibnu 'Abbās berkata: "Apabila seorang wanita sulit melahirkan, dua ayat dan dua kalimat berikut ini ditulis pada lembaran, kemudian dimasukkan ke dalam air dan airnya diminumkan. Adapun yang ditulis adalah: Dengan menyebut nama Allah Yang Maha Pengasih lagi Maha Penyayang. Tidak ada Tuhan selain Allah Yang Maha Agung, Maha Murah Hati, lagi Maha Mulia. Maha Suci Allah, Tuhan Pemilik langit dan Tuhan Pemilik Arasy yang mulia. Seakan-akan mereka pada hari mereka melihat hari kiamat itu, mereka tidak tinggal di dunia kecuali hanya sebagian hari atau hanya waktu dhuhanya saja. Pada hari mereka melihat adzab yang diancamkan kepada mereka merasa seolah-olah tidak tinggal di dunia melainkan sesaat pada siang hari. Inilah suatu pelajaran yang cukup dan tidak dibinasakan kecuali kaum yang fasik."

Dua ayat yang disebutkan di atas adalah Surat al-Nāziāàt ayat 46 dan Surat al-Ahqāf ayat 35. Kedua ayat di atas sama sekali tidak berhubungan dengan urusan kehamilan atau melahirkan. Kedua ayat tersebut menceritakan tentang kondisi yang akan dialami oleh orang fasik ketika di hari kiamat nanti. Akan tetapi dari kedua surat tersebut terdapat suatu spirit untuk melemahkan atau mengancam mereka. Mungkin, dengan melihat spirit tersebut, Ibnu 'Abbās meresepsi kedua ayat tersebut untuk melemahkan kesulitan yang dialami oleh perempuan yang akan melahirkan, hingga kemudian ia diberi kemudahan.

\section{c. Kemudahan Bangun Malam}

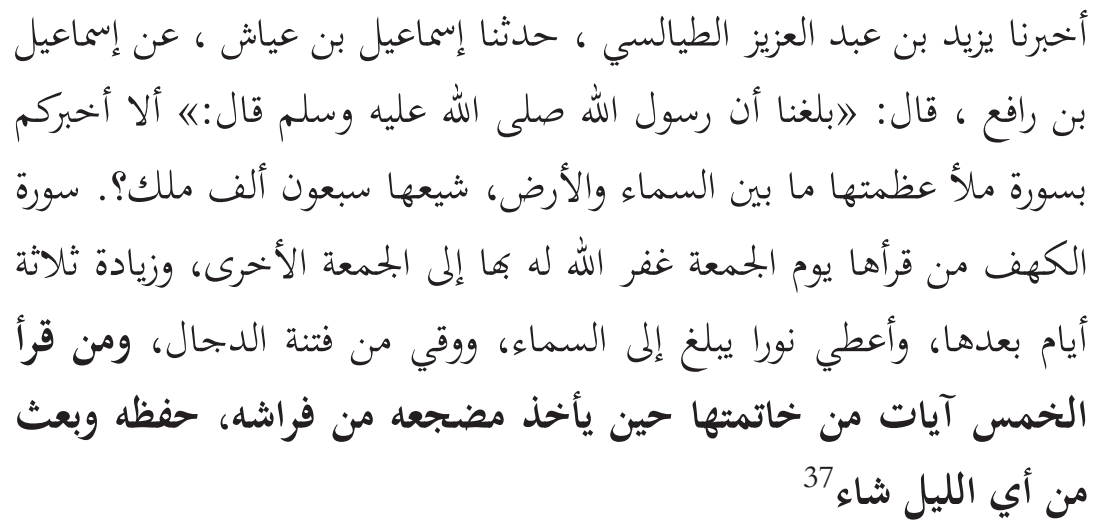

37 al-Ḍurais, Faḍail al-Qur'ān, hlm. 96. 
Telah mengabarkan kepada kami Yazīd bin 'Abd al-'Azīz al-Ṭayālisi, telah meriwayatkan kepada kami Ismāil bin 'Iyasy dari Ismail bin Rāfi', ia berkata: Telah sampai kepada kami bahwa Rasulullah saw. bersabda: Ingatalah! Aku akan mengabarkan kepadamu tentang surat yang keagungannya antara langit dan bumi, pengikutnya adalah 70000 malaikat. Ia adalah Surat al-Kahfi. Barangsiapa membacanya pada hari Jumat, maka Allah akan mengampuninya sampai hari Jumat berikutnya dan menambahkan tiga hari setelahnya. Allah akan memberikan cahaya yang sampai ke langit dan melindungi dari fitnah Dajjal. Dan barangsiapa yang membaca lima ayat terakhir dari surat ini ketika dia berbaring di tempat tidurnya, maka Allah akan menjaganya dan membangunkannya kapan pun yang ia kehendaki pada malam hari.

Riwayat di atas menceritakan perkataan Nabi saw. tentang beberapa keutamaan yang akan diperoleh ketika membaca Surat al-Kahfi. Selain beberapa keuntungan yang akan diperoleh di hari akhir nanti, orang yang membaca lima ayat terakhir dari surat al-Kahfi sebelum tidur, maka ia akan dijaga dan dibangunkan oleh Allah pada pada waktu yang diinginkannya di malam hari. Menurut beberapa riwayat, generasi awal Islam juga telah membuktikan hadis nabi tersebut. Misalnya di dalam Musnad al-Dārimi terdapat riwayat dari Zuhr al-Habisy yang berkata bahwa orang yang membaca akhir surat al-Kahfi dan ingin bangun qiyāmu al-lail, maka ia akan bangun pada waktu yang dikehendaki. Kemudian ia berkata, "kami telah mencobanya dan kami mendapatkannya." ${ }^{38}$ Dengan demikian, umat Islam pada masa lalu juga telah meresepsi Alquran dengan tujuan untuk mempermudah bangun malam, meskipun ayat yang dibaca tersebut tidak menyatakan tujuan yang diinginkan.

38 al-Dārimi, Sunan al-Dārimi, "Kitab Faḍāil al-Qurān”, no. 3272. Di dalam riwayat lain diceritakan bahwa pada masa sahabat, hal ini juga telah dilakukan oleh mereka. Misalnya riwayat tentang ibnu Abbas dan seorang lelaki yang bercerita bahwa ia berniat bangun jam 1 malam, tetapi kemudian ia tertidur. Kemudian Ibnu 'Abbās memerintahkan untuk membaca dua ayat terakhir dari Surat al-Kahfi agar bisa bangun malam sesuai dengan keinginan. Lihat al-Qurțubi, al-Tiżkār fì Afọali al-Ażkār, hlm. 267. 


\section{Untuk Memohon Keselamatan}

Bagi umat Islam, berdoa kepada Allah dapat menjadi usaha untuk mencegah berbagai kemungkinan buruk yang dapat terjadi. Selain itu, membaca Alquran yang menjadi pedoman hidup umat Islam juga dapat menjadi salah satu cara untuk memohon keselamatan. Salah satu surat yang banyak dibaca oleh umat Islam adalah Surat Yāsīn. Surat ini memiliki berbagai keutamaan yang dipercaya dapat memberikan keuntungan dunia dan akhirat bagi pembacanya. Selain yang telah dipaparkan pada poin sebelumnya, Surat Yāsīn juga dipercaya dapat memberikan keselamatan.

$$
\begin{aligned}
& \text { أن أبا بكر ، قال: قال رسول الله صلى الله عليه وسلم: السورة يس تدعى } \\
& \text { في التوراة: المعمة، قيل وما المعمة؟ قال: تعم صاحبها بخير الدنيا والآخرة، } \\
& \text { وتكابد عنه بلوى الدنيا والآخرة، وتدفع عنه أهاويل الآخرة، وتدعى المدافعة } \\
& \text { القاضية، وتدفع عن صاحبها كل سوء، وتقضي له كل حاجة، ومن قرأها } \\
& \text { عدلت له عشرين حجة، ومن سمعها، عدلت له ألف دينار في سبيل الله، واله } \\
& \text { ومن كتبها، ثخ شربها أدخلت جوفه ألف دواء، وألف نور، وألف يقين، } \\
& \text { وألف بركة، وألف رحة ونزعت منه كل غل، وكل داءها } 39
\end{aligned}
$$

Abu Bakar berkata: Rasulullah saw. bersabda: "Surat Yāsīn di dalam Taurat disebut sebagai al-Mu'imah". Lalu beliau ditanya, "Mu'imah itu apa, wahai Rasulullah? Beliau menjawab: "Pemiliknya diliputi kebaikan dunia dan akhirat, dicegah dari datangnya musibah dunia dan akhirat, dihindarkan dari ketakutan akhirat, diseru dari arah samping dan arah atas, segala kejahatan dihindarkan darinya dan ditunaikan segala hajatnya. Pahala membacanya sebanding dengan dua puluh kali pergi haji. Pahala orang yang mendengarnya sama dengan menafkahkan seribu dinar di jalan Allah. Orang yang menulisnya dan meminumnya, maka seribu obat, seribu cahaya, seribu keyakinan, seribu berkah, dan seribu

39 al-Durais, Faḍail al-Qur'ān, hlm. 100. Riwayat ini juga ditemukan di dalam Al-Qurțubi, al-Tiżkār fi Afọali al-Ażkār, hlm. 274 dan al-Suyūți, Jāmi' al-Masānid wa al-Marāsil, Juz, 5, hlm. 10. Di dalam keterangannya al-Suyūți menilai ḍa'îf riwayat yang disandarkan kepada Abū Bakar yang juga terdapat di dalam riwayat al-Ḍurais di atas. 
rahmat dimasukkan ke dalam perutnya. Setiap belenggu dan penyakit juga dicabut darinya.

Riwayat di atas menyebutkan, di antara keutamaan membaca Surat Yāsīn dapat mendatangkan kebaikan dan mencegah datangnya keburukan baik berupa musibah ataupun penyakit. Ini berarti, surat Yasin dapat memberikan keuntungan berupa keselamatan dari berbagai keburukan bagi pembacanya. Selain Surat Yāsinn, di dalam literatur klasik juga ditemukan ayat-ayat lain yang memiliki fungsi keselamatan. Misalnya, di dalam Mu'jam al-Ṭabrāni terdapat riwayat tentang ayat-ayat yang dibaca agar selamat ketika berkendara.

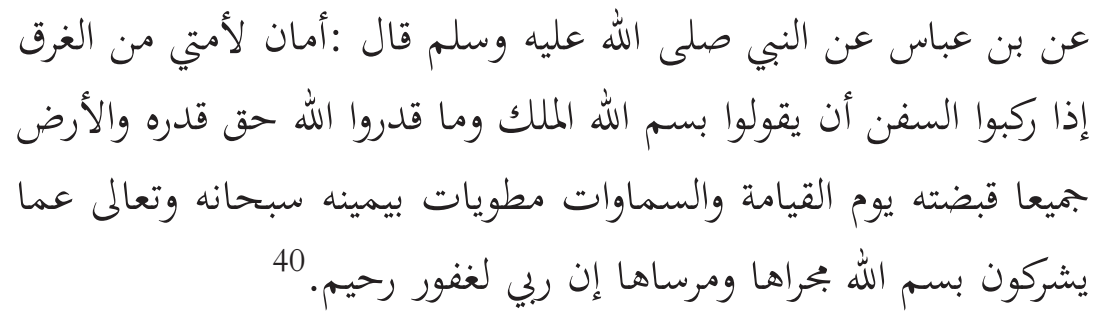

Dari Ibnu 'Abbās dari Nabi saw. beliau bersabda: Pengaman umatku dari tenggelam jika ia mengendarai perahu adalah dengan mengucapkan: "Dengan menyebut nama Allah yang Maha Menguasai. Dan mereka tidak mengagungkan Allah dengan pengagungan yang semestinya padahal bumi seluruhnya dalam genggaman-Nya pada hari kiamat dan langit digulung dengan tangan kanan-Nya. Maha Suci Tuhan dan Maha Tinggi Dia dari apa yang mereka persekutukan. Dengan menyebut nama Allah di waktu berlayar dan berlabuhnya. Sesungguhnya Tuhanku benarbenar Maha Pengampun lagi Maha Penyayang."

Riwayat dari Ibnu 'Abbās yang disandarkan kepada Nabi di atas menerangkan bacaan yang dapat dibaca ketika mengendarai perahu dengan tujuan agar tidak tenggelam. Bacaan yang disebut sebagai

40 al-Ṭabrāni, Mu'jam al-Ṭabrāni, "al-Ḍaḥhāk 'an Abi Hurairah", no. 12661, Juz 12, hlm. 124; Riwayat dengan jalur ini juga ditemukan dalam al-Suyūți, Jāmi' al-Masānid wa alMarāsil, no. 4470; Riwayat ini dengan jalur yang berbeda, dari Ḥasan bin 'Ali terdapat di dalam al-Qurțubi, al-Tiżkār fi Afọali al-Ażkār, hlm. 258; al-Suyūți, Fatḥ al-Kabīr (Beirut: Dar al-Fikr, t. Th), no. 2604, Juz 1, hlm. 258; al-'Asqalāni, al-Mațlab al-Āliyah (Beirut: Dar al-Fikr, 2003), Juz 8, hlm. 23. Di dalamnya terdapat komentar bahwa sanad

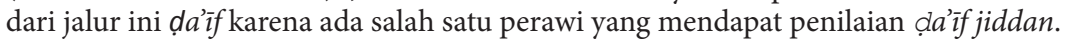


pengaman tersebut merujuk pada Surat al-Zumar ayat 67 dan Surat Hūd ayat 41. Kedua ayat tersebut menunjukkan keagungan Allah yang menguasai bumi, langit, dan seisinya termasuk laut tempat perahu berlayar. Dengan memuji keagungan Allah, kedua ayat tersebut kemudian diresepsi sebagai salah satu cara yang dapat dilakukan untuk mengharap keselamatan ketika mengendarai perahu.

Selain itu, ditemukan juga riwayat tentang ayat-ayat Alquran yang dibaca untuk tujuan menyelamatkan diri dari serangan hewan. Di dalam al-Tiżkār, al-Qurțubi menampilkan beberapa riwayat yang berkaitan dengan hal ini. Misalnya, riwayat di bawah ini adalah petunjuk agar tidak disakiti oleh anjing.

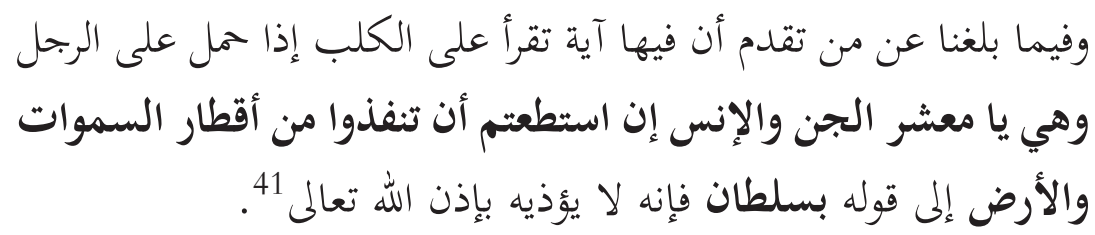

Dalam cerita yang telah sampai kepada kami dari orang-orang terdahulu, di dalamnya ada ayat yang dibacakan kepada anjing apabila dibawa seseorang, ayatnya yaitu: "Hai jama'ah jin dan manusia, jika kamu sanggup menembus (melintasi) penjuru langit dan bumi, maka lintasilah, kamu tidak dapat menembusnya melainkan dengan kekuatan". Maka anjing tidak akan menyakitinya dengan ijin Allah.

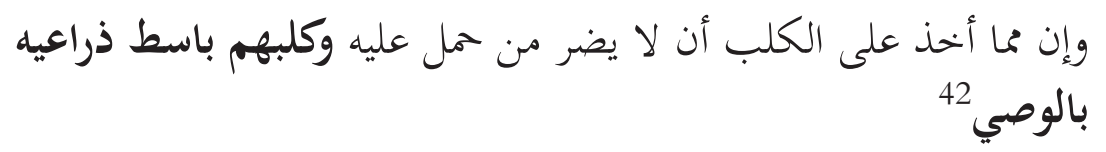

Dan ayat yang digunakan agar anjing tidak membahayakan orang yang membawanya adalah: "sedang anjing mereka mengunjurkan kedua lengannya di muka pintu gua".

Kedua riwayat tersebut tidak diketahui perawi dan sumber asalnya. al-Qurțubi hanya menyebutkan bahwa riwayat ini dari orang-orang terdahulu. Meskipun demikian, riwayat ini menunjukkan bahwa ayat- 
ayat Alquran telah diresepsi oleh umat Islam pada masa lalu untuk berbagai tujuan. Begitu juga dengan riwayat-riwayat yang disampaikan sebelumnya. Riwayat tentang resepsi terhadap Alquran sebagai bacaan yang dapat dibaca pada waktu tertentu dan untuk tujuan tertentu ditemukan di dalam berbagai literatur klasik. Selain yang telah disebutkan di atas, masih banyak riwayat tentang tema senada di dalam kitab-kitab tersebut. Riwayat-riwayat yang ditampilkan di atas hanyalah sebagian dari sekian banyak yang dapat menjadi gambaran praktik pembacaan Alquran untuk tujuan tertentu pada masa Islam awal. Sebagian bersumber langsung dari perkataan, perbuatan, dan konfirmasi dari Nabi saw. Di antaranya ada yang Șahīh, tetapi yang memiliki kualitas da îf juga tidak lebih sedikit. Sebagian yang lain bersumber dari para sahabat dan generasi setelahnya. Sumber dari masa ini terlihat lebih banyak, lebih beragam, dan lebih luas cakupannya.

\section{Transmisi dan Transformasi dalam Resepsi Alquran}

Dalam kajian resepsi Alquran, di dalam praktik tersebut terdapat proses transmisi dan tranformasi dari informasi yang terdapat dalam riwayat-riwayat hadis. Transmisi merupakan pengiriman (penerusan) pesan atau informasi dari seseorang kepada orang lain. ${ }^{43}$ Pesan yang disandarkan kepada Nabi ataupun para sahabat di atas, ditransmisikan dari satu orang ke orang lain, dari satu generasi ke generasi lain.

Menurut Rafiq, proses transmisi hadis-hadis tersebut juga melibatkan pembacaan pesan hadis dari para transmiter. Selain meneruskan riwayat hadis, mereka juga memahami informasi yang terkandung di dalam hadis. Ketika memahami riwayat hadis mereka dibatasi oleh dunianya masing-masing, dipengaruhi oleh ruang, waktu, dan pengetahuan yang dimiliki. Dengan adanya perbedaan konteks dan informasi yang ada di dalam hadis sebagai teks masa lalu, maka resepsi terhadap Alquran sangat mungkin melibatkan

43 KBBI Offline 1.5.1. 
pembacaan kreatif. Perbedaan konteks tersebut juga sangat mungkin dapat merubah bentuk resepsi dari satu pembaca ke pembaca lain, meskipun praktiknya relatif mirip. Perubahan bentuk resepsi tersebut dalam bahasa Rafiq disebut dengan Transformasi. ${ }^{44}$

Sebagai contoh misalnya di dalam al-Jāmi' al- Șaḥiḥ karya alBukhāri terdapat hadis tentang kisah sabahat yang menggunakan Surat Al-Fatihah untuk mengobati seseorang yang terkena sengatan kalajengking. Al- Bukhāri meletakkan riwayat hadis tersebut diantaranya di dalam "Kitab Faḍāil al-Qurān" dan "Kitab al-Tibb". Hal ini mengindikasikan bahwa menurut al-Bukhāri, Surat al-Fatihah memiliki keutamaan dan berkaitan dengan pengobatan. Pada generasi selanjutnya, hadis ini oleh al-Nawawi diletakkan pada sub bab "fī $m \bar{a}$ yuqra'u 'inda al-mariōi'. Al-Nawawi meresepsi Surat al-Fatihah dan Mu'awwizatain sebagai surat yang dapat dibaca di dekat atau untuk orang yang sedang sakit. Di dalam kitabnya terdapat keterangan bahwa hadis ini diambil dari riwayat al-Bukhari yang kemudian dipahami oleh al-Nawawi sebagai riwayat yang mengandung informasi tentang fungsi lain dari surat-surat Alquran. Begitu juga ketika meletakkan hadis tentang Surat Yasin di dalam " $f \bar{\imath} m \bar{a}$ yuqra 'u 'inda al-Mayyiti". Meskipun kualitas hadis tentang Surat Yasin dinilai lemah, akan tetapi direspon secara postif oleh al-Nawawi. Melalui riwayat hadis tersebut, ia meresepsi Surat Yasin sebagai surat Alquran yang dapat dibaca di dekat orang yang sedang sakit. Dengan demikian, berdasarkan teori Rofiq, al-Nawawi telah melakukan transformasi resepsi Alquran yang diperoleh dari informasi yang terdapat di dalam riwayat hadis.

Selain al-Nawawi, proses transmisi-transformasi resepsi Alquranjuga dilakukan oleh al-Mustagfiri di dalam kitabnya. Salah satunya, ia menempatkan hadis mauquf tentang keutamaan Surat al-Baqarah di dalam sub bab "Mațlabu mā Yuqra'u 'alā al-Majnūni". Di dalam keterangannya, hadis ini bersumber dari riwayat al-Darimi

44 Ahmad Rafiq, The Reception of the Quran in Indonesia: A Case Study o the Place of the Quran in a Non-Arabic Speaking Comuunity, A Disertation of The Temple University Graduate Board, Philadelphia, 2014, hlm. 179. 
di dalam "Kitab Faọaìil al-Qur’ān”. Hal ini mengindikasikan bahwa berdasarkan informasi di dalam hadis tersebut, al-Mustaghfiri melakukan transformasi resepsi Surat al-Baqarah sebagai surat yang dapat digunakan untuk menyembuhkan penyakit gila.

Proses transmisi-transformasi ini terus berlangsung di sepanjang kehidupan umat Islam yang terbentang dari masa Nabi hingga saat ini. Sehingga resepsi Alquran dari satu generasi sangat mungkin untuk ditiru secara kreatif oleh generasi selanjutnya, tergantung pada transmisi pengetahuan yang berlangsung, melalui teks atau praktik. ${ }^{45}$ Fenomena ini berlangsung di berbagai kehidupan umat Islam di berbagai tempat, termasuk di Indonesia. Kondisi sosial-budaya yang telah terbentuk ketika Islam datang ke Indonesia mempengaruhi proses pengajaran Islam. ${ }^{46}$

Salah satu bentuknya dapat dilihat dalam resepsi mereka terhadap Alquran. Misalnya saja, sebagaimana halnya umat Islam lainnya, setiap hari mereka membaca Alqurandi dalam salat. Alquranjuga senantiasa dibaca di masjid, di surau, atau di rumah sebagai salah satu bentuk ibadah mereka. Di samping itu, mereka juga membaca Alquran untuk tujuan lain, sebagaimana yang dilakukan oleh umat Islam di masa lalu. Akan tetapi, dengan latar belakang sosial budaya yang ada, mereka merespon informasi tentang Alquran secara kreatif. Respon mereka terhadap informasi tersebut kemudian terwujud dalam berbagai praktik pembacaan Alquran.

Di antaranya adalah tradisi Yasinan ${ }^{47}$. Kegiatan ini sudah menjadi tradisi yang banyak dilakukan oleh umat Islam di Indonesia, baik di

45 Ahmad Rafiq, "Sejarah Alquran: Dari Pewahyuan ke Resepsi (Sebuah Pencarian Awal Metodologis) dalam Sahiron Syamsudin (ed.), Islam Tradisi dan Peradaban (Yogyakarta: Bina Mulia Press, 2012), hlm. 75.

46 Ahmad Syafi'i Ma’arif, "Sublimitas Islam di Indonesia" dalam Abdul Karim, Islam Nusantara (Yogyakarta: Pustaka Book Publisher, 2007), hlm. 5

47 Yasinan merupakan istilah yang berasal dari salah satu nama surat di dalam Alquranyaitu Surat Yāsīn. Kemudian kata ini mendapat imbuhan "an" di belakangnya menjadi Yasinan untuk menyebut kegiatan membaca Surat Yāsīn. Lihat Abd. Mubarak, Tradisi Yasinan dalam Masyarakat Pambusuang Kecamatan Balanipa Kabupaten Polewali Mandar Sulawesi Barat, Skripsi Fakultas Ushuluddin dan Pemikiran Islam UIN Sunan Kalijaga, Yogyakarta, 2008. 
rumah-rumah, di desa, atau di pesantren yang biasanya bertujuan untuk mendoakan keselamatan kerabat atau orang-orang yang telah meninggal dunia. Bagi mereka, tradisi Yasinan ini bertujuan untuk memohon keselamatan bagi kerabat yang sedang ditimpa musibah seperti ketika sakit, ketika sakaratul maut, atau ketika ziarah kubur. Di samping itu, mereka juga percaya bahwa mengamalkan Yasinan pada waktu-waktu tertentu adalah anjuran agama. Dengan Yasinan, mereka juga dapat memperoleh keberkahan berupa ketentraman hati, kelancara rizki, dan terkabulnya hajat-hajat mereka. Pemahaman mereka ini didapatkan dari keterangan para ustad yang didasarkan pada riwayat-riwayat tentang keutamaan membaca Surat Yāsīn.

Selain Yasinan masih banyak lagi resepsi yang dilakukan oleh umat Islam Indonesia terhadap Alquran. Alquran 'dilibatkan' dalam berbagai lini kehidupan mereka dan hidup di berbagai ritus yang melingkari kehidupan mereka. Dalam bahasa Heddy, fenomena ini merupakan bentuk dari quranisasi kehidupan, ${ }^{48}$ atau dalam bahasa kajian Alquran disebut dengan The Living Qur'an, ${ }^{49}$ yaitu Alquran yang hidup dalam masyarakat. Sehingga, di dalam kajian ini terdapat fenomena tekstual (riwayat hadis) dan fenomena sosial-budaya-historis kehidupan suatu masyarakat yang meresepsi Alquran.

\section{Kesimpulan}

Dari paparan di atas, dapat terlihat bahwa keyakinan umat Islam terhadap keutamaan dan kekuatan yang dimiliki oleh Alquran mendasari berbagai praktik resepsi terhadap Alquran. Dengan

48 Heddy Shri Ahimsa Putra, “The Living Qur'an...., hlm. 251

49 Untuk memahami berbagai fungsi Alquransebagaimana yang disebut di atas, kajian ini tidak hanya dilakukan dengan menganalisis teks-teks hadis yang mendasari, akan tetapi juga perlu melihat dan memahami konteks sosial-budaya-historis yang ada di dalam suatu masyarakat. Kajian ini tidak digunakan untuk menentukan diterima atau tidaknya suatu hadis atau sumber praktik resepsi Alquran, akan tetapi untuk menentukan basis dan konteks dari praktik tersebut. Di samping itu, kajian ini juga bertujuan untuk menjelaskan proses kreatif yang dilakukan oleh seseorang atau masyarakat dalam memahami hadis atau teks masa lalu yang mendasari atau menstimulasi praktik di masanya. Lihat Ahmad Rafiq, "Sejarah Alquran..., hlm. 80. 
menggunakan pendekatan fungsional, dapat terlihat bahwa Alquran difungsikan oleh umat Islam dalam berbagai hal. Ada yang bersifat suci seperti memfungsikannya sebagai sarana mendapat balasan pahala, keberkahan Alquran, dan keselamatan akhirat. Di samping itu juga ada yang bersifat profan seperti menjadikan Alquran sebagai sarana keselamatan di dunia, kesembuhan penyakit, dan terkabulnya berbagai hajat di dunia.

Umat Islam telah melakukan berbagai proses kreatif dalam memahami dan menerima informasi yang berkaitan dengan keutamaan Alquran. Proses ini juga telah dilakukan oleh umat Islam pada masa awal sebagaimana yang telah direkam oleh riwayat-riwayat tentang keutamaan Alquran. Mereka melakukan proses kreatif terhadap informasi yang disampaikan oleh nabi, yang selanjutnya juga dipahami dan dipraktikkan oleh generasi selanjutnya. Dengan berbagai cara transmisi dan situasi sosial-budaya yang ada, proses ini mengalami tranformasi dalam bentuk praktik yang beragam yang didasarkan pada keyakinan terhadap kesucian, keutamaan, dan kekuatan yang dimiliki oleh Alquran.

\section{DAFTAR PUSTAKA}

Abd. Mubarak. Tradisi Yasinan dalam Masyarakat Pambusuang Kecamatan Balanipa Kabupaten Polewali Mandar Sulawesi Barat, Skripsi Fakultas Ushuluddin dan Pemikiran Islam UIN Sunan Kalijaga, Yogyakarta, 2008.

al-Durais. Fa ọāil al-Qurān wa mā Unzila min al-Qur'ān bi Makkah wa mā Unzila bi al-Madīnah. Beirut: Dār al-Fikr, 1987.

al-Firyābi. Façāil al-Qur'ān wa mā Jäa fìhi min al-Faọli wa fì Kam Yuqra' wa al-Sunnah fi żālika. Riyāọ: Maktabah al-Rusyd, 1989. al-Nasāi. Faḍāil al-Qurōan. Beirut: Dār Iḥyā’ al-'Ulūm, 1996. Al-Nawawi. al-Ażkār. Beirut: Dār al-Fikr, 1994. 
Al-Qurthubi. The Secret of Qur'an, terj. Muhammad Syafi'i Masykur. Yogyakarta: Mitra Pustaka, 2013.

CD Software al-Marja' al-Akbar li Turāś al-Islāmi, Vers. 3.0

CD Software Mausūiah al-Hadīs al-Syarīf.

Ma'arif, Ahmad Syafi'i. "Sublimitas Islam di Indonesia" dalam Abdul Karim, Islam Nusantara. Yogyakarta: Pustaka Book Publisher, 2007.

Mattson, Ingrid. Ulumul Quran Zaman Kita. Jakarta: Zaman, 2013.

Putra, Heddy Shri Ahimsa. “The Living Qur'an: Beberapa Perspektif Antropologis" dalam Jurnal Walisongo, Vol. 20, No. 1, 2012, hlm. 235260-.

Rafiq, Ahmad. "Faḍāil al-Qurān”" dalam Abdul Mustaqim, dkk, Melihat Kembali Studi Alquran: Gagasan, Isu, dan Tren Terkini. Yogyakarta: Idea Press, 2015.

Rafiq, Ahmad. "Sejarah Alquran: Dari Pewahyuan ke Resepsi (Sebuah Pencarian Awal Metodologis)" dalam Sahiron Syamsudin (ed.), Islam, Tradisi dan Peradaban. Yogyakarta: Suka Press, 2012.

Rafiq, Ahmad. The Reception of the Quran in Indonesia: A Case Study o the Place of the Qur'an in a Non-Arabic Speaking Comuunity, A Disertation of The Temple University Graduate Board, Philadelphia, 2014.

S.H. Nasr. Islam dalam Cita dan Fakta. Jakarta: LAPPENAS, 1981.

Shihab, M. Quraish. Tafsir al-Misbah: Pesan, Kesan dan Keserasian Alquran. Jakarta: Lentera Hati, 2007. 